\title{
Türkiye Vatandaşlarının Kırgız ve Kırgızistan İmajına Yönelik Algıları
}

Azamat MAKSUDUNOV, Department of Management, Faculty of Economics and Administrative Sciences, Kyrgyz Turkish Manas University, Kyrgyzstan; e-mail: azamat.maksudunov@manas.edu.kg

Murat AVCI, Department of Management, Institute of Social Sciences, Kyrgyz Turkish Manas University, Kyrgyzstan; e-mail: murat.avci@manas.edu.kg

\section{Turkish Citizens' Perceptions towards Kyrgyz and Kyrgyzstan Image}

\begin{abstract}
Academic studies on country's image have conducted since 1930. Creation of country image includes several key features as economic, politic, ecologic, technologic conditions, history and cultural background as well as human resources of that country. We can say that the country image as a subject attracts attention of academic studies. Although there are many studies on the image of Turkey in Kyrgyzstan, there is no published research on the image of Kyrgyzstan in Turkey. The main purpose of this study is to determine Turkish citizens' perception toward Kyrgyz and Kyrgyzstan. For this purpose, it had carried out survey among 358 participants. The findings suggested that Turkish citizen's perceptions toward Kyrgyz and Kyrgyzstan generally positive. However, there is a significant difference between participants who has already visited Kyrgyzstan and has not visited yet. In other words, after visiting Kyrgyzstan Turkish citizens' view is being changing in a negative direction.

Keywords : : Image, Country Image, Kyrgyzstan, Turkey.

JEL Classification Codes : $\quad$ M31, M38, F59.

Öz

Ülke imajı konusunda yapılan araştırmaların geçmişi 1930'lara kadar dayanmaktadır. Bir ülkenin ekonomik, politik, ekolojik, teknolojik durumu, tarihi ve kültürel geçmişi, insan kaynakları gibi özellikleri o ülkenin imajının oluşmasında belirleyici yer tutumaktadır. Ülke imajı üzerinde çok çalışılan bir konudur. Ancak, ilgili literatürde Türkiye'nin Kırgızistan'daki imajını konu alan çalışmalar bulunmasına karşın, Kırgızistan'ın Türkiye'deki imajı konusunda yapılan çalışmalara henüz rastlanmamaktadır. Bu çalışmada Türkiye vatandaşlarının Kırgız ve Kırgızistan algısının ortaya konulması hedeflenmektedir. Bu amaçla yapılan anket çalışması sonucu, 358 katılımcıdan elde edilen cevaplar değerlendirilmiştir. Araştırma sonuçlarına göre, Türkiye vatandaşlarının Kırgız ve Kırgiztan'a karşı genellikle olumlu bir algı sergiledikleri görülmüştür. Ancak, bu durum katılımcıların Kırgızistan'da bulunup bulunmadıklarına göre farklılık gösterdiği tespit edilmiştir. Diğer bir ifadeyle, Kırgızistan'a gelmeden önce Kırgızlar hakkındaki düşünceleri olumlu olan biri, Kırgızistan'a geldiğinde ve belirli bir süre kaldığında negatif yönde değiştiği görülmüştür.
\end{abstract}

Anahtar Sözcükler İmaj, Ülke İmajı, Kırgızistan, Türkiye. 


\section{Giriş}

Ülke imajı bir ülkenin diğer ülkelerle olan ilişkileri, yabancı sermaye yatırımlarının ülkeye çekimi, o ülkede üretilen ürünlerin dış piyasalarda tutundurulması, ülkenin bir turizm destinasyonu olarak seçilmesi gibi önemli ekonomik ve politik faaliyetlerde belirleyici rol oynamaktadır. Dolayısıyla, ülke imajı konusu stratejik öneme sahip olduğu söylenebilir. İlgili literatürde bu konu üzerine yapılan çalışmalar da bu görüşü desteklemektedir.

Konuyu Kırgızistan açısından ele aldığımızda, 1991'den buyana yabancı yatırımcıları, turistleri, yabancı ülke vatandaşlarının dikkatini çekmeye, uluslararası düzeyde olumlu imaj oluşturmaya yönelik çalışmalar yapılmaktadır. Geldiğimiz nokta itibariyle bazı olumlu sonuçlar olduğu kadar, olumsuz sonuçlar da söz konusu olmaktadır. Kırgızistan ekonomik ve politik anlamda bölge ülkeleri arasında en liberal ülke olarak bilinmektedir. Diğer taraftan, yaşanan toplumsal olaylar, gelişmişlik düzeyinin düşük olması gibi faktörler ülke imajını olumsuz yönde etkilemektedir. Kırgızistan'ın özellikle, ticari, ekonomik, siyasi ve kültürel alanlarda ilişkilerimizin olduğu ülkelerde imajının araştırılması güncel konular arasında yer almaktadır. Bu çalışmada ortak bir geçmiş, kültür ile yakınlık atfedilen, ekonomik ve politik anlamda da yakın ilişkileri olan Türkiye'de Kırgız ve Kırgızistan algısı ele alınmaktadır.

İlgili literatürde Türkiye'nin Kırgızistan'daki imajını konu alan çalışmalar bulunmaktadır (Akyürek, 2012; Gülcan vd., 2015), ancak Kırgızistan'ın Türkiye'deki imaj1 konusunda yapılan çalışmalara rastlanmamıştır. Bilindiği üzere, Kırgızistan için yabancı yatırımlar, ticaret ve turizm gibi alanlarında Türkiye'nin önemli yeri vardır. Ayrıca, ortak geçmişi olan ülke olması nedeniyle Kırgızistan'a karşı olumlu tutum söz konusudur. Ancak, bu olumlu tutum Kırgızistan'ı ziyaret ettikten sonra, Kırgızları ve Kırgızistan'ı yaşayarak gördükten sonra olumlu yönde mi, olumsuz yönde mi değişmektedir sorusu ortaya çıkmaktadır. Araştırma sonuçları, Kırgızistan - Türkiye arasındaki ilişkilerde görev alan kurum ve kuruluşlar açısından önem arz etmektedir.

\section{Literatür Taraması}

İmaj, zihnimizdeki çağrışımlar, hisler, tutumlar ve izlenimler ile bunların olumlu ve olumsuz değerlendirilmelerinden oluşur; akla gelen ilk özet resim ya da sembolik anlamdır (Ateşoğlu \& Türker, 2013: 115). İmaj bireysel olabileceği gibi, ürünlerle ve kurumlarla ilgili de olabilir. Ayrıca, genel olarak ülke bazında da ele alınabilmektedir. Ülke imajı insanların şu ya da bu ülkeye ilişkin inanç ve gösterimlerinden oluşan bir sonuç olarak tanımlanmaktadır (Martínez \& Alvarez, 2010: 749). Ülke imajı ülkeye ait çok sayıda bilgilerin, çağırışımların basitleştirilmiş halini temsil eder. Diğer bir ifadeyle, ülke imajı ülkenin ekonomisi, siyaseti, ekolojisi, insan kaynakları, tarihi ve kültürel geçmişi gibi farklı boyutlardan oluşmaktadır.

Ülke imajı konusunda yapılan araştırmaların geçmişi 1930'lara kadar dayandığı söylenebilir (Kusunoti, 1936; Katz \& Braly, 1933). Bu konuda yapılan çalışmaların bir kısmı ülkelerin genel olarak imajı ile ilgiliyken (Bakan, 2010; Nghie^m-Phu, 2015; Gülcan vd., 
2015), bazıları ülke imajının ürün ve hizmetlerin satın alınmasındaki etkisi (Ayyildiz \& Cengiz, 2007; Azadi et al., 2015; Öztürk \& Çakır, 2015) üzerinde odaklandığı görülmektedir.

Nghie^m-Phu (2015) tarafindan Vietnam'da iş, çalışma, eğitim, sağlık hizmet alma gibi farklı nedenlerle 12 aydan fazla bir süre ile bulunan 200 yabancı üzerinde yapılan çalışmada, ülke imajının ülkede bulunmaktan dolayı duydukları memnuniyet ve sadakat üzerinde etkili olduğu ortaya konulmuştur.

Bir diğer ülke imajı çalışması Bakan (2010) tarafından gerçekleştirilmiştir. Amsterdam Üniversitesi'nde Hollanda'lı 280 öğrenci üzerinde yaptığ çalışmada Türkiye hakkında bireylerin ilk aklına gelen olguları ortaya çıkarmak ve Türkiye için ülke imajını ölçmeye çalışmıştır. Araştırma sonuçlarına göre bireylerin aklına gelen ilk olgunun İstanbul olduğu tespit edilmiştir. Ayrıca Türk ve Türkiye'ye karşı düşüncelerinin olumlu olduğu ve Türk misafirperverliği dikkat çekmiştir.

Akyürek (2012) tarafından hazırlanan Kırgızistan'da Türk ve Türkiye imaj konulu araştırmasında öğrenciler, üniversite çalışanları ve akademisyenler olmak üzere toplam 344 denek üzerinde bir anket uygulamışlardır. Araştırma sonuçları ise Kırgızların Türkler ve Türkiye'ye bakış açıları orta düzeyde olduğu tespit edilmiştir. Ayrıca Kırgızlar Türk ürünlerini tercih etmekte ve Türkiye'ye eğitim ve seyahat amaciyla gitme konusunda istekli oldukları gözlemlenmiştir. Olumsuz görüşlerin de \%40 seviyelerinde olması Türkiyenin yeterince tanıtılmaması olarak bağlantı kurulmuştur.

Yine konuyla ilgili Gülcan vd., (2015) tarafindan yapılan bir başka çalışmada 564 öğrenci ile anket yapılmış ve Türkiye'nin Kırgızistan'daki imajı ölçümlenmeye çalışılmıştır. Araştırma sonuçlarına göre, ögrencilerin Türkiye ilgili alıgılarının olumlu olduğu ortaya çıkmıştır. Özellikle Kırgızistan - Türkiye Manas Üniversitesi öğrencisi olduktan sonra olumlu yönde değiştiği tespit edilmiştir.

Ülke imajı o ülkede üretilen markaların uluslararası pazarlardaki itibarı açısında da önem arz etmektedir.

Ayyıldız ve Cengiz (2007) tarafından 295 denekle Türkiye'de yaptıkları bir araştırmada ülke imajı ile müşteri sadakati arasında etkileşime dayalı model geliştirmek ve test etmek amaçlanmıştır. Sonuç olarak ülke imajı tüketici sadakatine ve müşteri sadakati öncülerine etki ettiği tespit edilmiştir.

Azadi vd., (2015) tarafından Iran'da yaptıkları çalışmada menşe ülke imajı marka değeri ve marka sadakati ile pozitive ilişkisi olduğu tespit edilmiştir. İlgili üreticilere marka imajını arttırmak için öncelikle üretici ülke markarlarının imajının arttırılması önerilmektedir.

Öztürk ve Çakır (2015) tarafından İstanbul'da yapılan bir araştırmada, Türkiye'nin imajı ve itibarı arasında yakın bir ilişkinin olduğu; ayrıca gerek yerli, gerekse yabancı 
menşeli marka tercihleri ile Türkiye'nin imajı ve itibarı arasında bir ilişkinin olmadığı ortaya konulmuştur. Dolayısıyla, yapılan araştırmada ülke imajının marka tercihine etkisi olmadığı yönde bir sonuç elde edilmiştir.

Ülke imajında turizm alanında yapılan destinasyon ile ilgili çalışmalar gelişmekte olan ülkeler için önemli yer tutmaktadır. Bununla ilgili Ateşoğlu ve Türker (2013) çalışmasında tatil amacıyla Antalya, İstanbul, Muğla ve Kapadokya bölgelerini ziyaret eden 1977 turist üzerinde bir anket araştırmasına yer vermişlerdir. Araştırma sonuçlarına göre, turistlerin algıladıkları Türkiye imajının yeterince yüksek olmadığı ve özellikle ziyaret öncesindeki imaj algısının çok düşük olduğu belirtilmektedir.

Assaker (2014) tarafından Çin, İngiltere, ABD ve Güney Kore olmak üzere dört farklı ülkeden 600 denekle yaptıkları bir çalışmada turistik bir destinasyon olarak Avustralya'nın imajı araştırılmıştır. Sonuçlara göre, imajın boyutlarını oluşturan faktörler olarak; doğal ve tanınmış turistik yerler, kültürel ve turistik hizmetlerin çeşitliliği, genel turistik atmosferin kalitesi, eğlence ve rekreasyon, genel çevre ve erişilebilirlik çıkmıştır. Özellikle, doğal ve tanınmış turistik yerler, ulaşılabilirlik genel imajın oluşmunda en çok etkisi olan iki boyut olduğu berlirtilmektedir.

Zhang vd. (2016) tarafından Çin'de 378 denekle yapılan bir araştırmada, ülke imajı, destinasyon imajı ve destinasyon değerlendirmesi arasındaki ilişkiler aranmıştır. Araştırma sonuçlarına göre, ülke imajı uluslararası turistlerin Çin’i bir turizm destinasyonu olarak değerlendirirken etkilendiği faktörlerden biri olarak bulunmuştur.

Görüldüğü gibi ülke imajı konusunda yapılan çalışmalarde ticari amaçlar ağırlıklı olmakla brilikte, bu konu siyasi, kültürel amaçarla da ele alınmaktadır. Ancak, imaj konusunda yapılacak işlerin başında ölçme sorunu gelmektedir. Literatürde ülke imajının ölçümü konusunda farklı çalışmaların bulunduğunu ve bir birlerine yakın ölçeklerin geliştirildiğini görmek mümkündür.

Park vd. (2014) tarafindan literatürde kullanılan bir ölçeği yeniden test etmek ve güncellemek amacıyla bir çalışma yapılmıştır. Yapılan faktör analizi sonucunda temel beş boyut belirlenmiş ve bu beş faktör toplam varyansın \%55.03 açıkladığı görülmüştür. Sözkonusu boyutlar sırasıyla; politika, ekonomi, teknoloji, kültür ve spordan oluşmaktadır. Beş boyut toplam 23 ifadeden oluşmaktadır. İnsanların herhangi bir ülke hakkında yukarıdaki faktörlere göre görüşlerinin toplamı o ülkenin imajını vermektedir.

Ülke imajının ölçümü konusunda bir diğer ölçek Lala vd. (2009) tarafından geliştirilmiştir. Pazarlama ve pazarlama dışı literatüre dayalı olarak temel yedi boyut belirlemişler ve daha sonra her bir boyutla ilgili değişkenleri oluşturmuşlardır. Daha sonra ölçeğin güvenirlilik ve geçerlilik testleri yapılmış ve ülke imajının ölçümlenmesinde güçlü bir ölçek olması hedeflenmiştir. Sonuçta geliştirilen ölçek toplam 21 ifade ve 7 boyuttan oluşmaktadır. Sözkonusu temel boyutlar sırasıyla; ekonomik durum, çatışma, politik yapı, mesleki eğitim, çalışma kültürü, çevre ve işgücünden oluşmaktadır. 
Görüldüğü gibi, ülke imajı konusu literatürde çok çalışılan bir konudur. Ülke imajı daha önce değinildiği gibi ticari, ekonomik, politik ilişkiler açısından önem arz etmektedir. Ayrıca, ülke imajı o ülkede üretilen ürünlerin değerini etkilemekte, turizm destinasyonu olarak ülkenin tercih edilip edilmemesinde etkili olmaktadır. Dolayısıyla, ülke imajı planlı bir şekilde yönetilmelidir. Bu sürecin ilk adımı da imajın ölçülmesidir.

\section{Araştırmanın Amacı ve Soruları}

Araştırmanın temel amacı, Türkiye vatandaşlarının Kırgızistan ve Kırgızlar hakkındaki düşüncelerini tespit etmektir. $\mathrm{Bu}$ çerçevede, araştırmada şu sorulara cevap aranmıştır:

1. Türkiye vatandaşlarının gözüyle Kırgızistan imajı nasıldır?

2. Öne çıkan faktörler nelerdir?

3. Katılımcıların Kırgızistan'da bulunup bulunmamasına göre Kırgızistan algısında istatistiksel açıdan anlamlı fark var mıdır?

Bu kapsamda amaca yönelik olarak aşağıdaki hipotez test edilmiştir:

$H_{1}:$ Kırgızistan'da bulunan Türkiye vatandaşlarının Kırgızistan algısı ile bulunmayan vatandaşların algısı arasından anlamlı fark vardır.

\section{Araştırmanın Yöntemi}

Araştırma, mevcut durumu ortaya koymaya yönelik bir alan araştırmasıdır. Türkiye vatandaşlarının gözüyle Kırgızistan imajını belirlemek için ölçme aracı olarak yapılandırılmış anket formları kullanılmıştır. Anket formunun hazırlanmasında, literatüre dayalı olarak daha önce yapılan benzer çalışmalardan (Lala vd., 2009; Ateşoğlu \& Türker, 2013; Park vd., 2014) yararlanılmıştır.

Anket üç bölümden oluşmaktadır. Birinci bölümde, katılımcıların cinsiyet, yaş, eğitim seviyesi vb. demografik bulunmaktadır. İkinci bölümde ise, katılımcıların Kırgızistan ve Kırgızlar hakkındaki düşünceleri, çağırışımlar, bilgi kaynaklarını ele alan sorulara yer verilmiştir. Üçüncü bölümde ise ülke olarak Kırgızistan imajının ölçüldüğü 5'li likert ölçeğinde hazırlanan, "1 kesinlikle katılmıyorum" "5 tamamen katılıyorum" şeklinde derecelendirilen 21 ifade yer almaktadır.

Hazırlanan anket formuyla bir pilot uygulama yapılmıştır. Çeviri hataları ve yanlış anlaşılabilecek ifadeler düzeltildikten sonra asıl uyglamaya geçilmiştir. Anket çalışması anketörler aracılığıyla yüz yüze ve online olarak Nisan - Mayıs 2016 aylarında tesadüfü olarak seçilen 400 gönüllülere eş zamanlı olarak uygulanmıştır. Anket uygulaması sonucunda 358 adet kullanılabilir anket elde edilmiştir.

Kullanılan ölçeğin güvenirliliği 21 değişken üzerinde hesaplanmış, Alpha katsayısı 0,91 olduğu görülmüştür. Bu sonuç, anketin yeterince güvenilir olduğunu göstermektedir. 
Sosyal Bilimler alanındaki çalışmalarda güvenilirlik katsayısının 0.65 'in üzerine olması beklenmekte ve genel olarak yeterli kabul edilmektedir.

Araştırma verilerinin analizinde SSPS 20.0 istatistiksel paket programı kullanılmış ve amaca yönelik istatistiksel analizlere tabi tutulmuştur. Aşağıda, uygulanan analizlerden elde edilen sonuçlar yer almaktadır.

\section{Araştırma Bulguları ve Değerlendirme}

Demografik özellikler itibariyle ankete katılanların yaklaşık \%40’1 kadın ve \%60’1 erkeklerden oluşmaktadır. Katılımcıların \%87'si bekâr ve geriye kalan \%13'lük kısmı evli olduğu görülmektedir. Yaş dağılımlarına baktığımıza da önemli bir kısmı 21-30 yaş arasındaki (\%75) üniversite öğrencilerinden oluştuğu (\%83) söyelenebilir.

\section{Tablo: 1}

Katılımcıların Demografik Özellikleri

\begin{tabular}{|c|c|c|c|c|c|}
\hline & $\mathbf{F}$ & $\%$ & & $\mathbf{F}$ & $\%$ \\
\hline Erkek & 212 & 59,2 & Evli & 47 & 13,1 \\
\hline \multirow[t]{2}{*}{ Kadın } & 146 & 40,8 & Bekar & 310 & 86,86 \\
\hline & & & Cevapsiz & 1 &, 3 \\
\hline \multirow[t]{2}{*}{ Toplam } & 358 & 100,0 & Toplam & 358 & 100,0 \\
\hline & $\mathbf{F}$ & $\%$ & & $\mathbf{F}$ & $\%$ \\
\hline 20 yaşa kadar & 45 & 12,6 & Öğrenci & 296 & 82,7 \\
\hline $21-30$ yaş arası & 270 & 75,4 & Kamusektörü & 22 & 6,1 \\
\hline 31 yaş ve üzeri & 43 & 12,0 & Özelsektör & 40 & 11,2 \\
\hline \multirow[t]{2}{*}{ Toplam } & 358 & 100,0 & Toplam & 358 & 100,0 \\
\hline & & & & $\mathbf{F}$ & $\%$ \\
\hline \multicolumn{3}{|c|}{ Kırgızistan'da bulunanlar } & & 172 & 48,0 \\
\hline \multicolumn{3}{|c|}{ Kırgizistan'da bulunmayanlar } & & 186 & 52,0 \\
\hline \multicolumn{3}{|c|}{ Toplam } & & 358 & 100,0 \\
\hline
\end{tabular}

Araştırmaya katılan toplam 358 katılımcıdan \%48 Kırgızistan'da bulunmakta veya bulunmuştur. Geriye kalan \%52 Kırgızistan’da henüz bulunmamıştır.

Araştırma çerçevesinde merak ettiğimiz bir diğer soru katılımcıların Kırgızistan hakkında hangi kaynaklardan en çok bilgi aldıklarını öğrenmekti. Araştırma sonuçlarına göre, en çok (katılımcıların \%29) Kırgızistan'da ikamet ederek, yaşayarak bilgi edindiklerini dile getirmişlerdir (Grafik 1). Anlaşılacağı gibi, bu seçenek sadece Kırgızistan’1 görenler için geçerlidir. Genel olarak ele alındığında temel bilgi kaynağı doğal olarak internet ön plana çıkmıştır. Katılımcıların \%24'ü interneti ve \%18'i arkadaş çevresini önemli bilgi kaynağı olarak işaretlemişlerdir. Dolayısıyla bu kanallar aracılığıyla gönderilen bilgilerin pozitif olması ülke imajını olumlu etkileyecektir. İnsanlar yüz yüze veya sosyal medya üzerinden düşüncelerini, görüşlerini anında paylaşmaktadırlar ve virütik bir etki yaratabilmektedir. Türkiye vatandaşları için Kırgızistan hakkında bilgi aldıkları kaynaklar 
içerisinde televizyon ve ders kitapları da yer almaktadır. Son zamanlarda Türk kanalları Kırgızistan ve diğer Türki cumhuriyetlerde özel programlar hazırlamaktadır. Ayrıca, son yıllarda TRT Avaz kanalı da faaliyet göstermektedir. Diğer taraftan, katılımcıların \%12 Kırgızistan hakkında hangi kaynaklardan bilgi aldığına dair net bir bilgisinin olmadığını belirtmişlerdir. Diğer kaynaklar; seyahat acenteleri, spor ve kültürel etkinlikler, gazete ve dergileri içermektedir.

\section{Grafik: 1}

\section{Katılımcıların Kırgızistan Hakkında Bilgi Aldıkları Kaynaklar}

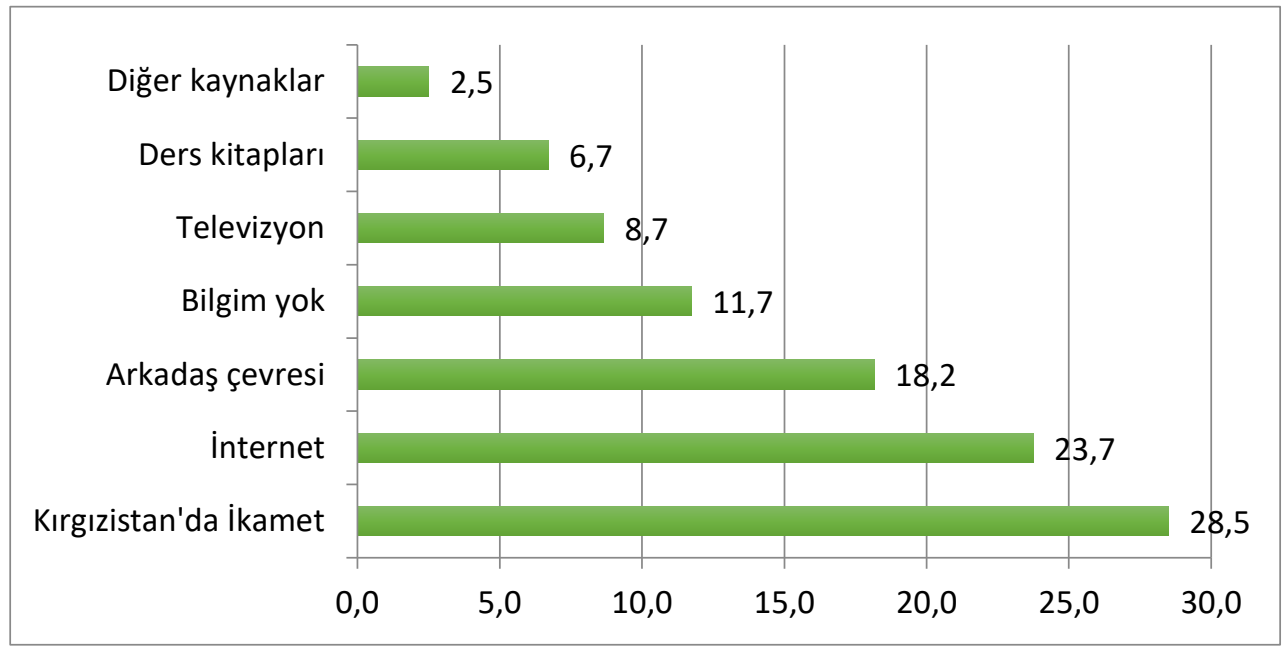

Ankete katılan Türkiye vatandaşları arasında Kırgız kavramıyla çağırışım yapan ilk üç seçenek Manas destanı (katılımcıların \%57), ardından çekik göz $(\% 44,4)$ ve C. Aytmatov $(\% 43,9)$ olarak karşımıza çıkmaktadır. Daha sonra, at, kımız, Ata yurt, Tanrı dağların akla geldiği belirtilmiştir. Manas destanı ve C. Aytmatov uluslararası düzeyde Kırgızistan markasını oluşturan en temel değerler olduğu bir kez daha kanıtlanmaktadır. Dikkat edilirse Kırgızistan hakkında çağırışım yapan seçenekler arasında devrimler, yoksulluk gibi negatif kelimeler de yer almaktadır. (Tablo 2). 
Tablo: 2

Katılımcıların Kırgızistan veya Kırgızlar Hakkındaki Çağırışımları

\begin{tabular}{lcc}
\hline & F & \% \\
\hline Manas Destanı & 204 & 57,0 \\
Çekik Göz & 159 & 44,4 \\
Cengiz Aytmatov & 157 & 43,9 \\
At & 143 & 39,9 \\
Kımız & 130 & 36,3 \\
Ata Yurt & 122 & 34,1 \\
Tanrı Dağları & 105 & 29,3 \\
Doğa & 60 & 16,8 \\
Devrimler & 30 & 8,4 \\
Yoksulluk & 24 & 6,7 \\
Diğer & 11 & 3,1 \\
\hline
\end{tabular}

Kardeş ülkelerin vatandaşları olarak Kırgızlar ile Türklerin arasında dil, din, tarih gibi ortak noktalarımızın varlı̆̆ı tarihi bir gerçektir. Ancak, söz konusu ortak noktalarımızın ne kadar farkındayız ve hangilerini ön planda görmekteyiz sorularını merak ettiğimizbir diğer sonuç aşağıdaki tabloda sunulmuştur. Araştırma sonucunda Türkiye vatandaşları Kırgızlarla Türkler arasında en temel ortak noktalarımız olarak dinimizi (\%51), daha sonra ortak geçmişimizi (\%49), kültürümüzü (\%33,0) düşünmektedirler. Bu sıralamayı gelenekler ve dil, yaşam tarzı ve giyim tarzı takip etmektedir. Katılımcılar arasında ortak noktalarımızın olmadığını (\%13) düşünenlerin olduğu da görülmektedir (Tablo 3).

Tablo: 3

\section{Katılımcılara Göre Kırgızlarla Türklerin Ortak Noktaları}

\begin{tabular}{lcc}
\hline & F & \% \\
\hline Din & 182 & 50,8 \\
Ortak geçmiş & 176 & 49,2 \\
Kültür & 118 & 33,0 \\
Gelenek & 107 & 29,9 \\
Dil & 104 & 29,1 \\
Ortak noktamız yok & 46 & 12,8 \\
Yaşam tarzı & 20 & 5,6 \\
Giyim tarzı & 19 & 5,3 \\
Diğer & 17 & 4,7 \\
\hline
\end{tabular}

Türkiye vatandaşlarının Kırgızlara karşı duygularında olumlu görüşler ön plana çıkmaktadır. Katılımcıların \%42'si Kırgızlara karşı sempati, \%34'ü sevgiyi en kuvvetli duygular arasında göstermişlerdir. Ayrıca, güvensizlik (\%20), nefret $(\% 5)$ gibi olumsuz duygular olduğu kadar, Kırgızlara karşı hiç bir duygu (\%22) hissetmediğini belirtenler de olmuştur (Tablo 4). 
Tablo: 4

Katılımcıların Kırgızlara Karşı Duyguları

\begin{tabular}{lcc}
\hline & F & \% \\
\hline Sempati & 151 & 42,2 \\
Sevgi & 122 & 34,1 \\
Hiçbirşey & 79 & 22,1 \\
Güvensizlik & 73 & 20,4 \\
Şüphe & 46 & 12,8 \\
Minnettarlık & 38 & 10,6 \\
Nefret & 18 & 5,0 \\
Korku & 14 & 3,9 \\
Diğger & 14 & 3,9 \\
\hline
\end{tabular}

Türkiye vatandaşlarının Kırgız halkıyla ilgili görüşleri bir takım ifadeler önerilerek alınmaya çalışılmıştır. Bu önermeler olumludan olumsuza kadar sıralanmıştır. Aşağıdaki tabloda bu ifadeleri destekleyenlerin yüzde dağılımları verilmiştir (Tablo 5). Genel olarak incelendiğinde Kırgızistan'da henüz bulunmayan Türkiye vatandaşlarının görüşleri Kırgızistan'da bulunanlara göre daha pozitif yönde olduğu söylenebilir. Diğer bir ifadeyle, Kırgızistan'a gelmeden önce Kırgızlar hakkındaki düşünceleri olumlu olan biri, Kırgızistan'a geldiğinde ve belirli bir süre yaşadğında bu durumun değiştiğini, Kırgızlar hakkında düşüncelerin negatif yönde değiştiği görülebilir. Örneğin, 'Kırgızlar soğuktur' ifadesine Kırgızistan'da bulunanlara (\%38) göre, Kırgızistan'da bulunmayanlar daha az katılmakta (\%16), ayrıca 'Kırgızlar samimidir' ifadesine de bulunanlara göre (\%37), bulunmayanlar (\%45) daha fazla katılmaktadır.

Tablo: 5

Katılımcıların Kırgız Halkıyla İlgili Görüşleri

\begin{tabular}{|c|c|c|c|c|}
\hline Kırgızistan'da Bulunanlar & & & $\tan \operatorname{ta}^{2}$ & nmayanlar \\
\hline Iffadeler & $\%$ & Toplam\% & $\%$ & Ífadeler \\
\hline Soğuk & 38,5 & & 16,2 & Soğuk \\
\hline Samimi & 37,4 & 100 & 45,5 & Samimi \\
\hline Kararsiz & 24,1 & & 38,3 & Kararsız \\
\hline Tembel & 47,9 & & 17,4 & Tembel \\
\hline Çalışkan & 35,6 & 100 & 38,7 & Çalışkan \\
\hline Kararsız & 16,5 & & 43,9 & Kararsız \\
\hline Agresif & 61,7 & & 18,6 & Agresif \\
\hline Nazik & 17,6 & 100 & 40,6 & Nazik \\
\hline Kararsız & 20,7 & & 40,8 & Kararsız \\
\hline Kibirli & 56,2 & & 13,5 & Kibirli \\
\hline Mütevazi & 26,1 & 100 & 44,1 & Mütevazi \\
\hline Kararsiz & 17,7 & & 42,4 & Kararsız \\
\hline Dürüst değil & 43,8 & & 6,7 & Dürüst değil \\
\hline Dürüst & 38,5 & 100 & 55,9 & Dürüst \\
\hline Kararsız & 17,7 & & 37,4 & Kararsız \\
\hline Güvenilmez & 45,5 & & 7,3 & Güvenilmez \\
\hline Güvenilir & 33,7 & 100 & 54,8 & Güvenilir \\
\hline Kararsız & 20,8 & & 37,9 & Kararsız \\
\hline Cahil & 36,4 & & 8,9 & Cahil \\
\hline Eğitimli & 42,3 & 100 & 53,3 & Eğitimli \\
\hline Kararsız & 21,3 & & 37,8 & Kararsız \\
\hline
\end{tabular}


Aynı şekilde önerilen tüm sıfatlar bazında Kırgızistan'1 henüz görmeyenlerin, Kırgızistan’ı gören ve yaşayanlara göre Kırgız halkıyla ilgili görüşleri daha pozitiftir.

Türkiye vatandaşlarının Kırgız halkıyla ilgili görüşlerinin yanısıra Kırgızistan hakkındaki görüşleri de alınmıştır. Bu konuda da Kırgızistan'da bulunmayanların görüşleri daha olumlu iken, Kırgızistan'da bulunanların görüşleri olumsuza doğru değiştiği gözlemlenmektedir (Tablo 6). Örnek vermek gerekirse, Kırgızistan'da bulunan Türkiye vatandaşları (\%56), bulunmayanlara göre (\%18) Kırgızistan’1 daha çok tehlikeli görmektedirler.

Tablo: 6

Katılımcıların Kırgızistan İle İlgili Görüșleri

\begin{tabular}{|c|c|c|c|c|}
\hline \multicolumn{2}{|l|}{ Kırgızistan'da Bulunanlar } & \multicolumn{3}{|c|}{ Kırgızistan'da Bulunmayanlar } \\
\hline$\dot{\text { Ifadeler }}$ & $\%$ & Toplam\% & $\%$ & Ifadeler \\
\hline Tehlikeli & 56,1 & & 17,9 & Tehlikeli \\
\hline Güvenli & 23,7 & 100 & 42,1 & Güvenli \\
\hline Kararsiz & 20,2 & & 40,0 & Kararsiz \\
\hline Zayif & 63,0 & & 18,5 & Zayif \\
\hline Güçlü & 15,6 & 100 & 32,5 & Güçlü \\
\hline Kararsiz & 21,4 & & 49,0 & Kararsiz \\
\hline Gelişmemiş & 70,5 & & 21,9 & Gelişmemiş \\
\hline Gelişmiş & 21,9 & 100 & 38,2 & Gelişmiş \\
\hline Kararsiz & 7,6 & & 39,9 & Kararsiz \\
\hline Kirli & 54,1 & & 12,9 & Kirli \\
\hline Temiz & 32,5 & 100 & 43,2 & Temiz \\
\hline Kararsız & 13,4 & & 43,9 & Kararsiz \\
\hline Antilaik & 32,1 & & 10,6 & Antilaik \\
\hline Laik & 40,7 & 100 & 34,2 & Laik \\
\hline Kararsiz & 27,2 & & 55,2 & Kararsiz \\
\hline Antidemokratik & 30,1 & & 10,1 & Antidemokratik \\
\hline Demokratik & 46,7 & 100 & 40,4 & Demokratik \\
\hline Kararsiz & 23,2 & & 49,5 & Kararsiz \\
\hline Pahalı & 49,1 & & 12,9 & Pahalı \\
\hline Ucuz & 23,6 & 100 & 36,1 & Ucuz \\
\hline Kararsiz & 27,3 & & 51,0 & Kararsiz \\
\hline Fakir & 57,2 & & 24,1 & Fakir \\
\hline Zengin & 13,2 & 100 & 24,7 & Zengin \\
\hline Kararsiz & 29,6 & & 51,2 & Kararsiz \\
\hline
\end{tabular}

Ancak, laiklik, demokratiklik gibi ifadelerde Kırgızistan'da bulunanlar ile bulunmayanlar bir birlerine yakın cevaplar vermişlerdir. Bilindiği gibi, Kırgızistan liberal ekonomik ve siyasi uygulamalarıyla, bölge ülkeler arasında en demokratik ülke olarak bilinmekte ve bu durum uluslararası medya ve sosyal medyada yoğun olarak yer aldığı için insanların bu konuda bilgisi var denilebilir. Belirtilmesi gereken bir diğer konu, Türkiye vatandaşlarından Kırgızistan'da bulunanlar özellikle Kırgızistan’ı bir taraftan gelişmemiş ve fakir olarak görmekte, diğer taraftan pahalı olduğunu düşünmektedirler.

Araştırma çerçevesinde Türkiye vatandaşlarının gözüyle Kırgızistan ülke imajını ölçmek için Lala vd. (2009) tarafından geliştirilen 21 ifadeden oluşan ölçek kullanılmış ve belirtilen ölçeğin yapı geçerliliğini test etmek ve ülke imajının alt boyutlarını belirlemek 
amacıyla Açıklayıcı Faktör Analizi (Exploratory Factor Analysis) yapılmıştır. Faktör analizi, Temel Bileşenler Analizi (Principal Component Analysis) yöntemi ve Kaiser Normalizasyonlu Varimax dik döndürme yöntemi kullanılarak gerçekleştirilmiştir. Faktör yükleri 0.50 'in altında bulunan maddeler analizden çıkartılarak, faktör analizi 19 madde üzerinde tekrarlanmıştır. Analiz sonucunda, elde edilen Bartlett Küresellik Testi (Bartlett's Test of Sphericity) değerleri değişkenler arasında faktör analizi yapmaya yeterli düzeyde ilişki olduğunu göstermektedir $(\mathrm{p}=.000$, Ki Kare 3,202E3). Ayrıca Kaiser-Meyer-Olkin Örneklem Yeterliliği Ölçüsü $(, 883)$ toplanan veri setinin faktör analizi yapmaya uygun olduğunu göstermektedir.

Tablo: 7

Faktör Analizi Sonuçları

\begin{tabular}{|c|c|c|c|c|}
\hline Faktörler & FY & Özdeğer & AV $(\%)$ & Güv( $\alpha)$ \\
\hline 1.Faktör: İsgü̈cü ve Çallşma Kültürü & & 7,062 & 21,535 & ,886 \\
\hline Kırgızistan'da çalışanlara değer verilir &, 771 & & & \\
\hline İş yeri koşulları Kırgızistan'da genellikle güvenlidir &, 755 & & & \\
\hline Kırgızlar bir çalışan olarak genellikle çok iyi davranır & ,753 & & & \\
\hline Kırgız bir çalışan olarak genellikle çok güvenilir &, 736 & & & \\
\hline Kırgızlar bir çalışan olarak genellikle ayrıntılara dikkat eder & ,639 & & & \\
\hline Kırgızlar bir çalışan olarak genellikle çok çalışkandır & ,619 & & & \\
\hline Kırgızlar bir çalışan olarak genellikle iş alanında iş bilgisi yüksek kişilerdir &, 574 & & & \\
\hline 2.Faktör: Çevre & & 1,831 & 13,590 & 900 \\
\hline Kırgızistan çevre konusunda titiz davranmaktadır. &, 844 & & & \\
\hline Kırgızistan çevre korunmasında yüksek standartları sürdürür &, 813 & & & \\
\hline Kırgızistan çevre kirliliği konusunda duyarlıdır &, 784 & & & \\
\hline 3.Faktör: Siyasi Yapı ve Halk & & 1,588 & 11,909 & ,695 \\
\hline Kırgızistan vatandaşları büyük bir özgürlüğe sahiptir & ,752 & & & \\
\hline Kırgızistan hükümetinin siyasi sistemi çok demokratiktir &, 705 & & & \\
\hline Kırgızlar bir çalışan olarak genellikle okumuş/tahsil görmüş kişilerdir & ,654 & & & \\
\hline Kırgızistan'1 çok beğeniyorum &, 620 & & & \\
\hline 4.Faktör: Ekomik Koşullar & & 1,187 & 11,803 & ,778 \\
\hline Kırgızistan ekonomisi sanayiye dayanır & ,819 & & & \\
\hline Kırgızistan ekonomisi gelişmiştir & ,804 & & & \\
\hline Kırgızistan teknolojik açıdan gelişmiş bir ülkedir &, 760 & & & \\
\hline 5.Faktör: Uluslararası İlişkiler & & 1,088 & 8,301 & ,693 \\
\hline Kırgız hükümeti Türkiye ile işbirliği içindedir &, 865 & & & \\
\hline Kırgızistan ileTürkiye arasında ticari ilişkiler dengelidir & ,796 & & & \\
\hline Toplam Varyans (\%) & & & 67,13 & ------ \\
\hline Kaiser-Meyer-Olkin Örnekleme Yeterliliği Ölçüsü & & & & 883 \\
\hline Bartlett Küresellik Testi & & değeri .000 & Ki Kare & $3,202 \mathrm{E} 3$ \\
\hline
\end{tabular}


Faktör analizi sonucunda, özdeğeri (eigenvalue) 1'den büyük 5 faktör/boyut ortaya çıkmıştır ve bu 5 faktör toplam varyansın \%67,13’ünü açıklamaktadır. Güvenirlik değerleri (Cronbach alpha) 0,90 ile 0,69 arasında değişen bu faktörler sırasıyla; Işgücü ve Çalışma Kültürü, toplam varyansın \%21,53'ünü, Çevre faktörü \%13,59'unu, Siyasi Yap1 ve Halk faktörü \%11,90’’nı, Ekomik Koşullar faktörü \%11,80’ini ve beşinci faktör ise Uslararası İlişkiler \%8,30’unu açıklamaktadır.

Araştırma çerçevesinde Kırgızistan’ın algılanan ülke imajı Türkiye vatandaşlarının Kırgızistan'da bulunup bulunmamasına göre farklılık gösterip göstermeyeceğinin ortaya konulması hedefelenmişti. Faktör analizi sonucu ortaya konulan beş faktörün söz konusu iki gruba (Kırgızistan'da bulunanlar ve bulunmayanlar) göre farklılık olup olmadığı bağımsız örneklem T testi ile sınanmıştır. Test sonuçlarına göre, 3ncü ve 5nci faktörde farklılık bulunmamıştır, diğer faktörlerde farklılık olduğu tespit edilmiş ve $\mathrm{H}_{1}$ hipotezi kabul edilmiştir.

Tablo: 8

Kırgızistan İmajı Boyutlarındaki Algılanan Farklılıklar

\begin{tabular}{|c|c|c|c|c|c|c|}
\hline & & $\mathbf{N}$ & Ort. & Std.Sap. & Sig. & $\mathbf{H}_{1}$ \\
\hline \multirow{2}{*}{ 1. Factor } & Kırgızistan'da Bulunanlar & 173 & 2,4791 &, 80634 & \multirow{2}{*}{, 000} & \multirow{2}{*}{ Kabul } \\
\hline & Kırgizistan'da Bulunmayanlar & 185 & 3,1266 &, 50140 & & \\
\hline \multirow{2}{*}{ 2. Factor } & Kırgizistan'da Bulunanlar & 173 & 2,4778 & 1,14923 & \multirow{2}{*}{, 000} & \multirow{2}{*}{ Kabul } \\
\hline & Kırgizistan'da Bulunmayanlar & 185 & 3,1423 & ,60356 & & \\
\hline \multirow{2}{*}{ 3. Factor } & Kırgızistan'da Bulunanlar & 173 & 3,0231 &, 81977 & \multirow{2}{*}{, 246} & \multirow{2}{*}{ Red } \\
\hline & Kırgizistan'da Bulunmayanlar & 185 & 2,9378 &, 55000 & & \\
\hline \multirow{2}{*}{ 4. Factor } & Kırgızistan'da Bulunanlar & 173 & 1,9509 & ,76101 & \multirow{2}{*}{, 000} & \multirow{2}{*}{ Kabul } \\
\hline & Kırgizistan'da Bulunmayanlar & 185 & 2,5297 & 63739 & & \\
\hline \multirow{2}{*}{ 5. Factor } & Kırgızistan'da Bulunanlar & 173 & 3,3295 & ,89319 & \multirow{2}{*}{, 727} & \multirow{2}{*}{ Red } \\
\hline & Kırgızistan'da Bulunmayanlar & 185 & 3,3595 & ,72736 & & \\
\hline
\end{tabular}

Birinci Factör olan İşgücü ve Çalışma Kültürü ve ikinci faktör olan çevre konularınada Kırgızistan'da bulunan (ort. 2,5) ve bulunmayan (ort. 3,1) Türkiye vatandaşlarının görüşleri bir birinden farklıdır. Diğer bir ifadeyle, işgücü ve çalışma kültürü, çevre konularında Kırgızistan'da bulunanlar daha olumsuz düşünmektedirler. Ek olarak dördüncü faktör olan Ekonomik Koşullar konusunda her iki grup olumsuz görüş bildirmekle beraber, Kırgızistan'da bulunan grup (ort. 1,9), bulunmayanlara (ort. 2,5) göre Kırgızistan ekonomik açıdan gelişmemiş olduğuna daha fazla vurgu yapmaktadır. Üçüncü faktör olan Siyasi Yapı ve Halk, beşinci faktör olan Uluslararası İlişkiler konularında gruplar arasında istatistiksel olarak anlamlı farklılık yoktur. Her iki grubun bu konulardaki görüşler aynı düzeydedir. 


\section{Sonuç}

Ülkenin ekonomik, politik, kültürel, ekolojik ve teknolojik durumu gibi faktörler o ülkenin imajını oluşturan temel boyutlar olarak karşımıza çıkmaktadır. Ayrıca, ülke imajının oluşmunda, ülke hakkında bilgi veren kaynakların ve bu kaynaklarda yer alan bilgilerin önemi büyüktür. Ülke imajı stratejik öneme sahip bir konu ve planlı bir çalışmayı gerektirir. İmaj yönetiminde ilk adım, imajın ölçümlenmesi ve mevcut durumun tespit edilmesidir.

Türkiye vatandaşlarının Kırgızistan ve Kırgız halkı hakkındaki temel bilgi kaynakları içerisinde, Kırgızistan ziyaretini dikkate almadığımızda; internet ve arkadaş çevresi en önemli kaynaklar olarak karşımıza çıkmaktadır. Bu kanallarda yer alan bilgiler objektiflikten uzak ve negatif özellikte de olabilmekte, neticede ülke imajına ciddi zararlar vermektedir. Dolayısıyla bu kanallar aracılığıyla gönderilen bilgilerin daha çok pozitif olması ülke imajını olumlu etkileyecektir. Bu konuda, ülkemizi ziyaret eden Türkiye vatandaşlarının sayısını arttırarak, onların yaşadıkları olumlu tecrübeler yine internet, tv veya medya araçları ile karşı tarafa aktarılarak imaj güçlendirilebilir. Türkler için Kırgızistan hakkında en çok Manas destanı ve C. Aytmatov'u çağırıştırmakta ve Kırgızlar ile Türkler arasında din, ortak geçmiş ve kültür en temel ortak noktalar olduğunu düşünmektedirler.

Kırgızistan ülke imajını oluşturan; Iş̧ücü ve Çalışma Kültürü, Çevre, Siyasi Yapı ve Halk, Ekomik Koşullar ve Uluslararası İlişkiler olmak üzere temel 5 faktör ortaya çıkmaktadır. İlgili literatürde ülke imajını oluşturan boyutların hemen hemen hepsi yer almaktadır. Literatürde bu boyutlardan farklı olarak teknoloji, çatışma gibi faktörlerin yer aldığı söylenebilir. Türkiye vatandaşları genel olarak Kırgızlara ve Kırgızistan'a karşı olumlu duygular içersinde olduğu söylenebilir. Ancak, araştırma sonuçlarına göre, bu durum Türklerin Kırgızistan'da bulunup bulunmamasına göre farklılık göstermektedir. Diğer bir ifadeyle, Kırgızistan’a gelmeden önce Kırgızlar hakkındaki düşünceleri olumlu olan biri, Kırgızistan'a geldiğinde, belirli bir süre yaşadığında bu durumun negatif yönde değiştiği söylenebilir. $\mathrm{Bu}$ durumda, sadece Türkiye vatandaşlarına karşı değil, genel olarak Kırgızistan imajını oluşturan boyutlarla ilgili iyileştirme faaliyetleri gerekmektedir.

\section{Kaynaklar}

Akyürek, S. (2012), Kırgızistan'da Türkiye ve Türk Algısı, Rapor No: 43, Mart, Bilge Adamlar Araştırma Merkezi, Ankara.

Assaker, G. (2014), "Examining a hierarchical model of Australia's destination image”, Journal of Vacation Marketing, 20(3), 195-210.

Ateşoğlu, İ. \& A. Türker (2013), “Türkiye’yi Ziyaret Eden Turistlerin Algıladıkları Ülke İmajı ve Olumsuz Algılara İlişkin Çözüm Önerileri”, Yeni Fikir Dergisi, 10, 112-135.

Ayyildiz, H, \& E. Cengiz (2007), “Country Image Effect on Customer Loyalty Model”, Innovative Marketing, 3(2), 44-64.

Azadi, R. \& B. Yousefi \& H. Eydi (2015), "The Impact of Brand Country-of-Origin Image on the Formation of Brand Equity in the Sports Apparel Industry", Universal Journal of Industrial and Business Management, 3(3), 67-73. 
Bakan, Ö. (2010), “The Image of Turkey in The Eyes of Dutch University Student”, Türkiyat Araşıtırmaları Dergisi,

<https://www.selcuk.edu.tr/dosyalar/files/303/16\%20\%c3\%96mer\%20bakan.pdf>, 27.06.2016.

Öztürk, R.G. \& H.Ö. Çakır (2015), "Ülke İmajının ve Ülke İtibarının Marka Tercihine Etkisinde Menşe Ülke Kavramının Rolü: Türk Tüketiciler Üzerine Bir Araştırma”, Global Media Journal TR Edition, 5(10), 317-340.

Gülcan, B. \& T. Cüneyt \& B. Erdem \& S. Karabaş (2015), "Kırgızistan-Türkiye Manas Üniversitesi Öğrencilerine Göre Türkiye İmajı”, Manas Sosyal Araştırmalar Dergisi, 4(1), 91-116.

Kusunoti, K. (1936), "Mental characteristics of the Japanese as seen by Japanese and American students", Japanese Journal of Applied Psychology, 4, 232-237.

Katz, D. \& K. Braly (1933), "Racial stereotypes of one hundred college students", Journal of Abnormal and Social Psychology, 28, 280-290.

Lala, V. \& A.T. Allred \& G. Chakraborty (2009), “A Multidimensional Scale for Measuring Country Image”, Journal of International Consumer Marketing, 21, 51-66.

Martínez, S.C. \& M.D. Alvarez (2010), "Country versus Destination Image in a Developing Country", Journal of Travel \& Tourism Marketing, 27, 748-764.

Nghie^m-Phu, B. (2015), "Country image, country attachment, country loyalty, and life satisfaction of foreign residents in Vietnam", Tourism and Hospitality Research, 0(0), 1-16.

Park S-B, R. \& M.J. Kim \& A. Choi J-S. (2014), "Redevelopment of Country Image Scale Questionnaire", Net Journal of Social Sciences, 2(2), 53-59.

Zhang, J. \& B. Wu \& A.M. Morrison \& C. Tseng \& C. Ying-Chen (2016), "How Country Image Affects Tourists' Destination Evaluations: A Moderated Mediation Approach", Journal of Hospitality \& Tourism Research, 10, 1-27. 